\title{
Pola Asuh Orang Tua Terhadap Karakter Anak di Raudhatul Athfal Al-Fityah Pekanbaru
}

\section{Fitri Sriyani}

Universitas Islam Negeri Sultan Syarif Kasim Riau, Indonesia

Email:fitrisriyani72@gmail.com

\section{Sariah}

Universitas Islam Negeri Sultan Syarif Kasim Riau, Indonesia

Email: syariab b@yaboo.co.id

\begin{abstract}
The purpose of this study is to have or not the influence of parenting parents at home against the character of children in Raudhatul Athfal Al-Fityah Pekanbaru. Subjects in this study were parents of students at Raudhatul Ahfal Al-Fityah Pekanbaru. For the population in this study is the parents of students in $\mathrm{RA}$ Al-Fityah which amounted to 63 people. Data collection techniques are done through observation, questionnaires, interviews and documentation. While data analysis technique used is product moment correlation technique. From the results of statistical analysis using product moment correlation techniques can be seen that there is a significant influence parenting parents at home against the character of children in Raudhatul Athfal Al-Fityah Pekanbaru with index numbers of 0.942 is greater than 0.345. So, there is a significant effect of parenting patterns at Home to the character of the child in Raudhatul Atbfal Al-Fityah Pekanbaru.
\end{abstract}

Keywords: Parenting Patterns, Children Character

\begin{abstract}
Abstrak
Penelitian ini bertujuan untuk mengetahui ada atau tidaknya pengarub pola asub orang tua di rumah terhadap karakter anak di Raudhatul Athfal Al-Fityah Pekanbaru. Penelitian ini dilakukan di $\mathrm{R} A$ Al-Fityah Pekanbaru. Penelitian ini merupakan penelitian korelasi product moment. Populasi dari penelitian ini adalab orang tua murid di $\mathrm{RA}$ Al-Fityah Pekanbaru yang berjumlah 63 orang. Pengumpulan data dilakuan menggunakan angket, wawancara, observasi dan dokumentasi. Analisis data dilakukan menggunakan teknik korelasi product moment. Hasil penelitian ini menunjukekan pengarub yang signifikan antara pola asub orang tua di rumab terhadap karakter anak di $\mathrm{R} A$ Al-Fityah Pekanbaru dengan perolehan angka indeks 0,942 lebih besar dari " $r$ " tabel baik pada taraf signifikan 5\% =0,266 maupun pada taraf signifikan 1\% =0,345. Dengan demikian disimpulkan bahwa terdapat pengaruh yang signifikan antara Pola Asub Orang Tua di Rumah terhadap Karakter Anak di Raudhatul Athfal Al-Fityah Pekanbaru.
\end{abstract}

Kata Kunci: Pola Asub Orang Tua; Karakter Anak 


\section{PENDAHULUAN}

Masa depan bangsa Indonesia sangat ditentukan oleh karakter generasi penerusnya, dalam hal ini adalah anak usia dini. Aristoteles mengungkapkan bahwa ada dua keunggulan dan kehebatan bangsa yang disebut dengan buman excelemt. Pertama, excelent of thought, yaitu keunggulan dan kehebatan dalam pemikiran. Kedua, excelent of character, yaitu keunggulan dan kehebatan dalam karakter. Keunggulan dan kehebatan yang kedua menjadi penentu keberhasilan suatu bangsa, sedangkan keunggulan dan kehebatan yang kedua sebagai pendukungnya.

Mulyasa (2014:67) mengungkapkan bahwa pendidikan karakter akan sangat tepat jika di implementasikan sejak dini, yaitu sejak anak belajar di lembaga Pendidikan Anak Usia Dini (PAUD) seperti Kelompok Bermain (KB), Taman Kanak-Kanak (TK) atau Raudhatul Athfal (RA). Menurutnya, pendidikan karakter bagi anak usia dini memiliki makna yang lebih tinggi dari pendidikan moral karena tidak hanya berkaitan dengan masalah benar dan salah, tetapi bagaimana menanamkan kebiasaan (habit) mengenai berbagai perilaku yang baik dalam kehidupan sehingga anak usia dini memiliki kesadaran, pemahaman yang tinggi, kepedulian, dan komitmen untuk melakukan kebaikan dalam kehidupan sehari-hari.

Namun benarkah bahwa untuk membangun karakter anak dapat diberikan secara instan? Cukup dengan paket program pendidikan disekolah yang hanya diberikan selama beberapa jam saja? Lilis Satria berdasarkan hasil surveynya (2010) terhadap 65 lembaga Pendidikan anak Usia Dini yang menerapkan pendidikan karakter di Jawa Barat, diketahui bahwa kendala yang dihadapi dalam menerapkan pendidikan karakter sekolah terletak pada orang tua. Kurangnya pemahaman orang tua tentang bagaimana cara pengasuhan atau pola asuh yang benar dalam membentuk karakter anak, menjadi kendala dalam kegiatan pembiasaan siswa seharihari, sehingga proses pendidikan karakter yang diterapkan di sekolah berjalan kurang maksimal.

Anak termasuk individu unik yang mempunyai eksistensi dan memiliki jiwa sendiri, serta mempunyai hak untuk tumbuh dan berkembang secara optimal sesuai dengan iramanya masing-masing yang khas. Masa kehidupan anak sebagian besar berada dalam lingkup keluarga. Karena itu, keluargalah yang paling menentukan terhadap masa depan anak, begitu pula corak anak dilihat dari perkembangan sosial, psikis, fisik, dan religiusitas juga ditentukan keluarga. Rifa Hidayah (2009:13) Rasulullah saw bersabda,

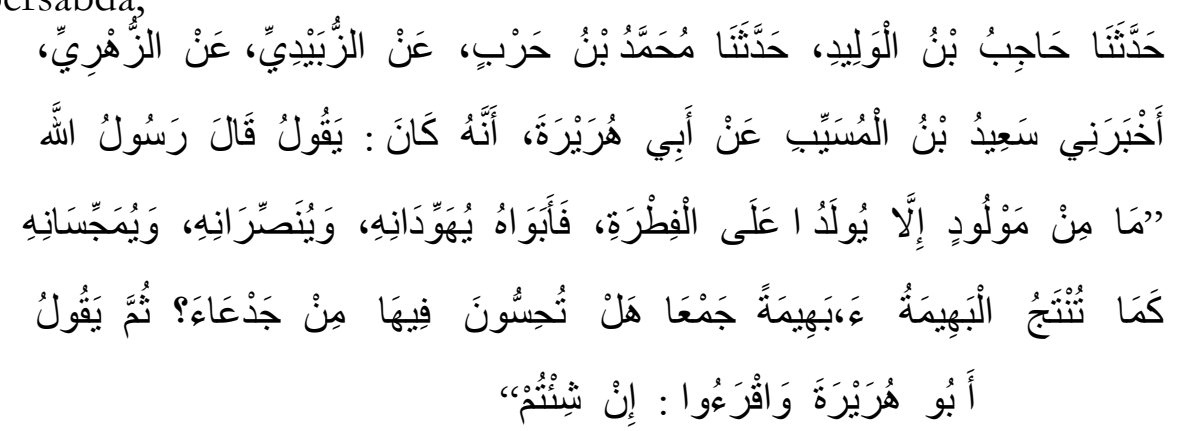


"Hâjib bin al-Walid menceritakan kepada kami (dengan mengatakan) Muhammad bin harb menceritakan kepada kami (yang berasal) dari al-Zubaidi (yang diterima) darfi al-Zuhri (yang mengatakan) Sa'id bin al-Musayyab memberitahukan kepadaku (yang diterima) dari Abu Hurairah bahwa ia berkata, Rasulullah saw bersabda: "Setiap anak lahir (dalam keadaan) fitrah, kedua orang tuanya (memiliki andil dalam) menjadikan anak beragama Yahudi, Nasrani, atau bahkan beragama Majusi, sebagaimana binatang ternak memperanakkan seekor binatang (yang sempurna anggota tubuhnya). Apakah anda mengetahui di antara binatang itu ada yang cacat/putus (telinganya atau anggota tubuhnya yang lain)" (HR. Muslim)

Hadis ini memperkuat bahwa pengaruh orang tua sangat dominan dalam membentuk kepribadian seseorang dibandingkan dengan faktor lainnya. Kedua orang tua mempunyai tanggung jawab yang lebih besar dalam mendidik anaknya. Oleh karena itu, orang tua harus menjadi teladan yang baik dan sebagai madrasah pertama yang akan mengajarkan anaknya agama, serta moral dan akhlak yang baik.

Dalam Al-Qur'an, Allah SWT berfirman:

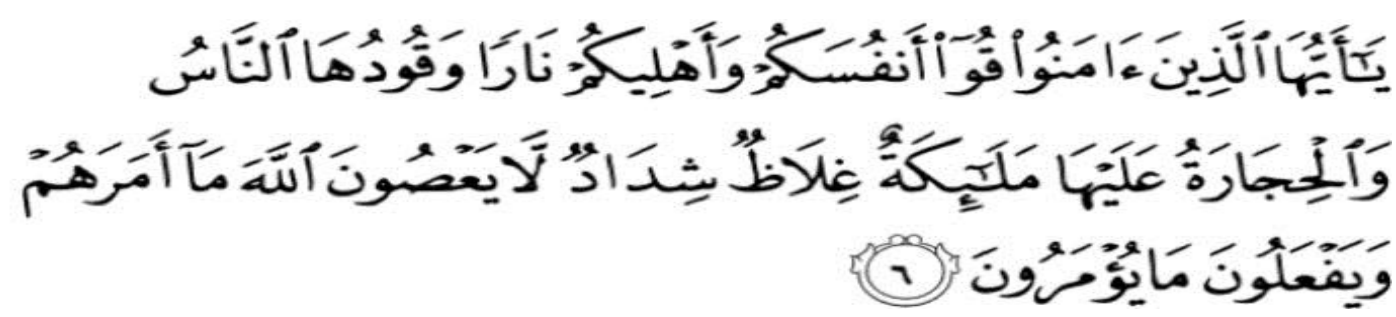

api neraka yang bahan bakarnya adalah manusia dan batu; penjaganya malaikatmalaikat yang kasar, keras, dan tidak mendurhakai Allah terhadap apa yang diperintahkan-Nya kepada mereka dan selalu mengerjakan apa yang diperintahkan. (Q.S At-Tahrim:6)

Ayat ini menjelaskan bahwa setiap keluarga bertanggung jawab dalam beriman dan mengerjakan ibadah ketaatan kepada Allah dan mengajarkan anggota keluarganya berbuat segala hal yang menjauhkan dari api neraka, misalnya mengajarkan tauhid dan beriman kepada Allah, berdakwah, berakhlak yang baik, saling tolong menolong dalam kebaikan. Dan juga orang tua bertanggung jawab mendidik anaknya dengan sebaik-baiknya agar anaknya beriman dan bertakwa kepada Allah, mengasuh anak dengan pola asuh yang baik agar terbina karakter anak yang baik dimulai sejak usia dini, mengarahkan anak untuk tumbuh dan menemukan jalan hidupnya dalam rangka berbuat ketaatan kepada Allah dan berakhlakul karimah kepada sesama manusia.

Membentuk karakter merupakan proses yang berlangsung seumur hidup, anakanak akan tumbuh menjadi pribadi yang berkarakter jika ia tumbuh di lingkungan yang berkarakter pula, dengan begitu fitrah anak yang dilahirkan suci bisa berkembang optimal. Dalam hal ini maka ada tiga pihak yang mempunyai peranan penting dalam membentuk karakter anak yaitu: keluarga, sekolah dan komunitas.

Dalam pendidikan karakter, keluarga merupakan tempat pembentukan karakter utama bagi anak.

Menurut Marzuki (2015:69), dalam keluarga, orang tualah yang menjadi tempat pertama pembentukan karakter anak. Dalam keluargalah anak-anak pertama 
kali mendapatkan pendidikan akhlak (karakter) disamping juga mendapatkan sosialisasi berbagai hal yang tumbuh dan berkembang dalam keluarga. Dalam keluarga, anak banyak melakukan proses pendidikan nilai dari orang tuanya, seperti tentang cara bertutur kata, berpikir dan bertindak. Orang tualah yang menjadi model utama dalam hal pendidikan karakter.

Akan tetapi, nyatanya penulis menemukan bahwa tidak semua orang tua memiliki kompetensi yang memadai untuk menjadi pendidik, kurang memberikan contoh yang baik bagi anak, kurang memberikan hak-hak anak untuk memperoleh pendidikan karakter yang baik di masa-masa awal pertumbuhannya. Padahal karakter anak itu diawali melalui pendidikan dan pembiasaan baik yang diperolehnya sejak dini.

Penelitian ini bertujuan untuk membantu dan mempermudah mengambil tindakan perbaikan selanjutnya dalam menangani permasalahan yang berkaitan dengan pola asuh orang tua yang mempengaruhi karakter anak baik di rumah maupun di sekolah.

Menurut Kuhn pola asuh merupakan sikap orang tua dalam berhubungan dengan anak-anaknya. Sikap ini dapat dilihat dari berbagai segi, antara lain dari cara orang tua dalam menerapkan berbagai peraturan kepada anak, memberikan hadiah dan hukuman, dan dalam memberikan tanggapan kepada anak. Intinya pola asuh orang tua adalah cara mendidik yang dilakukan orang tua kepada anak-anaknya baik secara langsung maupun tidak langsung.

Dian Noviyanti (2013:52) berpendapat bahwa " Sembilan puluh persen yang diingat anak dari orang tua adalah bidden massage dari perilaku, ekspresi, penyikapan, dan refleks biologis lainnya. Sedangkan pesan verbal (kata-kata) hanya sedikit pengaruhnya dalam pembentukan perilaku anak."

Melalui pola asuh yang dilakukan oleh orang tua, anak belajar tentang banyak hal, termasuk karakter. Tentu saja pola asuh otoriter (yang cenderung menuntut anak untuk patuh terhadap segala keputusan orang tua) dan pola asuh permissif (yang cenderung memberikan kebebasan penuh pada anak untuk berbuat) sangat berbeda dampaknya dengan pola asuh demoratis (yang cenderung mendorong anak untuk terbuka, namun bertanggung jawab dan mandiri) terhadap hasil pendidikan karakter anak. Artinya, jenis pola asuh yang diterapkan oleh orang tua terhadap anaknya menentukan keberhasilan pendidikan karakter anak oleh keluarga.

\section{a. Macam-Macam Pola Asuh Orang Tua}

Secara umum, Baurimind mengkategorikan pola asuh menjadi tiga jenis, yaitu:

(1) pola asuh authoritarian (otoriter); (2) pola asuh authoritative, dan (3) pola asuh permissive. A.Rahmat Rosyadi (2013:26)

a. Pola asuh authoritarian (otoriter)

Pola asuh otoriter adalah pola asuh dimana orang tua terlalu banyak menuntut dan sangat kurang merespon dan menanggapi keinginan anak.

Pola asuh ini penekanan asuhannya pada kekuatan kontrol orang tua kepada anak dengan cara:

1) Orang tua berupaya membentuk, mengontrol dan mengevaluasi sikap dan tingkah laku anaknya secara mutlak sesuai dengan aturan orang tua. 
2) Orang tua senang memberi tekanan secara verbal dan kurang memperhatikan masalah saling menerima dan memberi diantara orang tua dan anak.

3) Orang tua menekan kebebasan (independent) atau kemandirian (otonomi) secara indrividual kepada anak.

b. Pola Asuh Permisif

Pola asuh permisif adalah pola asuh yang penekanan asuhannya serba membolehkan dengan penunjukkan kasih sayang yang berlebihan serta disiplin yang rendah. Adapun ciri-cirinya adalah:

1) Orang tua membolehkan atau mengizinkan anaknya untuk mengatur tingkah laku yang mereka kehendaki dan membuat keputusan sendiri kapan saja.

2) Orang tua memiliki sedikit peraturan di rumah

3) Orang tua sedikit menuntut kematangan tingkah laku, seperti menunjukkan kelakuan/ tatakrama yang baik atau membimbing untuk menyelesaikan tugas-tugas.

c. Pola asuh Authoritatif (otoritatif)

Pola asuh otoritatif adalah pola asuh yang mendorong anak agar mandiri tetapi masih menetapkan batasan-batasan dan pengendalian atas tindakan mereka. Adanya musyawarah, memperlihatkan kehangatan dan kasih sayang. Pola asuh ini menghargai anak secara pribadi dengan memberikan rasa tanggung jawab berdasarkan pada aturan, dengan cara:

1) Menghargai minat dan keputusan anak

2) Mencurahkan cinta dan kasih sayang setulusnya

3) Tegas dalam menerapkan aturan dan menghargai perilaku baik

4) Melibatkan anak dalam hal-hal tertentu.

Untuk membentuk karakter yang baik dapat dilakukan melalui pendidikan dan pelatihan secara terus menerus dan dimulai dalam keluarga. Karena sifat karakter dapat dipengaruhi lingkungannya, maka penanaman nilai-nilai agama, moral dan budi pekerti sangat penting dilakukan sejak dini. Budi pekerti anak merupakan sekumpulan sifat-sifat dimana seseorang mencontoh dan meniru lingkungannya serta sangat dipengaruhi oleh pembinaan sejak usia dini. Sedangkan moral yang berarti adat istiadat dapat diartikan sebagai norma yang menata sikap dan perilaku manusia yang sesuai dengan standar sosial.

Ratna Megawangi mengungkapkan bahwa setidaknya ada sembilan nilai yang kemudian menjadi sembilan pilar karakter yang selayaknya dijadikan acuan dalam implementasi pendidikan karakter, antara lain:

1) Cinta kepada Allah dan kebenaran

2) Tanggung jawab, disiplin dan mandiri

3) Amanah

4) Hormat dan santun

5) Kasih sayang, peduli dan kerjasama

6) Percaya diri, kreatif dan pantang menyerah

7) Adil dan berjiwa kepemimpinan

8) Baik dan rendah hati 
9) Toleran dan cinta damai

\section{METODE}

Penelitian ini dilaksanakan di Raudhatul Ahfal (RA) Al-Fityah, Kec. Tampan Pekanbaru pada bulan Januari- Maret 2018. Populasi dalam penelitian ini adalah orang tua murid di RA Al-Fityah yang berjumlah 63 orang. Dalam melakukan penelitian ini, peneliti memberikan sebanyak 63 angket untuk orang tua, yang diberikan melalui kepala sekolah RA Al-Fityah Pekanbaru. Teknik pengumpulan data dalam penelitian ini menggunakan angket, observasi, wawancara dan dan dokumentasi. Sedangkan teknik analisis data dalam penelitian ini digunakan rumus korelasi product moment.

\section{HASIL DAN PEMBAHASAN}

\section{Uji Validitas dan Reabilitas}

Dari 34 item pertanyaan, di dapat 10 item pertanyaan variable $\mathrm{X}$ dikatakan valid dan terdapat 14 item pertanyaan variabel $\mathrm{Y}$ dikatakan valid. Sedangkan sebanyak 10 item pertanyaan tersebut memiliki $r$ hitung $<\mathrm{r}$ table $(0,334)$ sehingga dikatakan tidak valid dan tidak dapat digunakan sebagai intrumen penelitian.

Tabel 1. Hasil Uji Reliabilitas

\begin{tabular}{llll}
\hline Variabel & Reabilitas Coefficient & Alpha & Ket \\
\hline $\mathrm{X}$ & 10 item pertanyaan & 0,613 & Reliabel \\
$\mathrm{Y}$ & 14 item pertanyaan & 0,749 & Reliabel \\
\hline Sumber: Data Olahan 2018 & &
\end{tabular}

\section{Pembahasan}

Dalam penelitian ini, penulis menyebarkan sebanyak 63 angket berisi pertanyaan variabel $\mathrm{X}$ dan variabel $\mathrm{Y}$ kepada 63 responden yang terdiri dari orang tua murid, dan angket yang dikembalikan kepada responden adalah sebanyak 59 angket sehingga penulis mengambil data sampel sebanyak 59 dari 63 responden.

Dari perhitungan uji korelasi product moment, hasil dari $\mathrm{r}_{\mathrm{xy}}$ adalah 0,942 dan berdasarkan tabel koefisien korelasi " $\mathrm{r}$ " product moment taraf signifikan 5\%, 0,942 lebih besar dari 0,266 dan taraf signifikan 1\%, maka 0,942 lebih besar dari 0,345. Dengan demikian, dapat disimpulkan bahwa hipotesis alternative $(\mathrm{Ha})$ yang diajukan dalam penelitian ini berupa "ada pengaruh pola asuh orang tua di rumah terhadap karakter anak di Raudhatul Athfal Al-Fityah Pekanbaru dapat diterima, dan $\mathrm{H}_{0}$ ditolak.

Selanjutnya, mengacu pada tabel interpretasi dari nilai $r$, dapat disimpulkan bahwa 0,942 terletak di antara 0,80 - 1,000 yang berarti korelasi pola asuh orang tua terhadap karakter anak di Raudhatul Athfal Al-Fityah Pekanbaru terletak pada kategori tinggi. Dengan demikian, besar kontribusi pola asuh orang tua terhadap karakter anak adalah 88,73\%. Sedangkan sisanya, karakter anak dipengaruhi oleh variabel lain. 


\section{TABEL}

Dalam observasi ini, penulis menggunakan pedoman observasi dengan kriteria yaitu:

1. Berkembang sangat baik (BSB) pada rentang skor $76-100 \%$

2. Berkembang sesuai harapan (BSH) pada rentang skor $56-75 \%$

3. Mulai berkembang (MB) pada rentang skor $41-55 \%$

4. Belum berkembang (BB) pada rentang skor $<40 \%$

Tabel 2. Kondisi Awal Observasi Karakter Anak

\begin{tabular}{|c|c|c|c|c|c|}
\hline No & Komponen Indikator & $\begin{array}{c}\text { Skor } \\
\text { Faktual }\end{array}$ & $\begin{array}{l}\text { Skor } \\
\text { Ideal }\end{array}$ & $\%$ & Kriteria \\
\hline 1. & $\begin{array}{l}\text { Mengucapkan do'a-do'a pendek yaitu: do'a } \\
\text { sebelum belajar, do'a kedua orang tua, do'a } \\
\text { naik kendaraan }\end{array}$ & 20 & 63 & 32 & $\mathrm{BB}$ \\
\hline 2. & Mengucapkan Alhamdulillah & 25 & 63 & 40 & $\mathrm{BB}$ \\
\hline 3. & $\begin{array}{l}\text { Menyelesaikan tugas dari sekolah secara } \\
\text { mandiri }\end{array}$ & 15 & 63 & 24 & BB \\
\hline 4. & Mentaati peraturan di sekolah & 17 & 63 & 27 & $\mathrm{BB}$ \\
\hline 5. & $\begin{array}{l}\text { Membantu teman yang kesusahan dalam } \\
\text { mengerjakan tugas sekolah }\end{array}$ & 20 & 63 & 32 & BB \\
\hline 6. & $\begin{array}{l}\text { Bersalaman dengan orang tua ketika akan } \\
\text { masuk ke sekolah }\end{array}$ & 19 & 63 & 30 & $\mathrm{BB}$ \\
\hline 7. & Membuang sampah pada tempatnya & 23 & 63 & 36 & $\mathrm{BB}$ \\
\hline 8. & $\begin{array}{l}\text { Tidak marah saat tidak mendapat mainan } \\
\text { kesukaan }\end{array}$ & 13 & 63 & 21 & $\mathrm{BB}$ \\
\hline & Jumlah & 152 & 63 & 242 & $\mathrm{BB}$ \\
\hline
\end{tabular}

Berdasarkan tabel di atas, dapat diketahui bahwa pada skor akhir tertinggi terdapat pada indikator 2 yaitu anak mengucapkan Alhamdulillah dengan skor akhirnya 25 , persentase $40 \%$, berada pada kriteria BB. Skor akhir terendah terdapat pada indikator 1 yaitu Mengucapkan do'a-do'a pendek yaitu: do'a sebelum belajar, do'a kedua orang tua, do'a naik kendaraan berada pada skor 20 dan persentase $32 \%$, indikator 3 yaitu menyelesaikan tugas dari sekolah secara mandiri yang berada pada skor 15 dan persentase $32 \%$ berada pada kategori BB, indikator 4 yaitu anak menaati peraturan sekolah yang berada pada skor 17 dan persentase 27 berada pada kategori BB, pada indikator 5 yaitu Membantu teman yang kesusahan dalam mengerjakan tugas sekolah berada pada skor 20 dan persentase $32 \%$ berada pada kategori BB, pada indikator 6 yaitu Bersalaman dengan orang tua ketika akan masuk ke sekolahberada pada skor 19 dan persentase 30\% berada pada kategori BB,pada indikator 7 yaitu Membuang sampah pada tempatnyaberada pada skor 23 dan persentase 36 beradapada kategori BB,indikator 8 yaitu anak tidak marah saat tidak mendapat mainan kesukaan dengan skor akhir 13 dan persentase $21 \%$ berada pada kategori BB. 
Tabel 3. Tabel Observasi Karakter Anak Pada Kondisi Pertemuan Kedua

\begin{tabular}{|c|c|c|c|c|c|}
\hline No & Komponen Indikator & $\begin{array}{c}\text { Skor } \\
\text { Faktual }\end{array}$ & $\begin{array}{l}\text { Skor } \\
\text { Ideal }\end{array}$ & $\%$ & Kriteria \\
\hline 1. & $\begin{array}{l}\text { Mengucapkan do'a-do'a pendek yaitu: do'a } \\
\text { sebelum belajar, do'a kedua orang tua, do'a } \\
\text { naik kendaraan }\end{array}$ & 25 & 63 & 43 & $\mathrm{BSH}$ \\
\hline 2. & Mengucapkan Alhamdulillah & 30 & 63 & 48 & $\mathrm{BSH}$ \\
\hline 3. & $\begin{array}{l}\text { Menyelesaikan tugas dari sekolah secara } \\
\text { mandiri }\end{array}$ & 25 & 63 & 43 & BSH \\
\hline 4. & Mentaati peraturan di sekolah & 20 & 63 & 32 & $\mathrm{BB}$ \\
\hline 5. & $\begin{array}{l}\text { Membantu teman yang kesusahan dalam } \\
\text { mengerjakan tugas sekolah }\end{array}$ & 23 & 63 & 37 & $\mathrm{BB}$ \\
\hline 6. & $\begin{array}{l}\text { Bersalaman dengan orang tua ketika akan } \\
\text { masuk ke sekolah }\end{array}$ & 30 & 63 & 43 & BSH \\
\hline 7. & Membuang sampah pada tempatnya & 23 & 63 & 37 & $\mathrm{BB}$ \\
\hline \multirow[t]{2}{*}{8.} & $\begin{array}{l}\text { Tidak marah saat tidak mendapat mainan } \\
\text { kesukaan }\end{array}$ & 17 & 63 & 27 & BB \\
\hline & Jumlah & 193 & 63 & 309 & $\mathrm{BB}$ \\
\hline
\end{tabular}

Berdasarkan tabel diatas, disimpulkan bahwa terdapat skor akhir tertinggi dengan kategori BSH yaitu pada indikator 1, 2,3 dan enam. Dengan indikatorngucapkan do'a-do'a pendek yaitu: do'a sebelum belajar, do'a kedua orang tua, do'a naik kendaraan, Mengucapkan Alhamdulillah, Menyelesaikan tugas dari sekolah secara mandiri, Bersalaman dengan orang tua ketika akan masuk ke sekolah. Sedangkan pada kaetogri BB terdapat pada kategori 4, 5, 7 dan 8, yaitu dengan indikator 4, Mentaati peraturan di sekolah yang berada pada skor 20 dengan persentase $32 \%$, indikator 5 Membantu teman yang kesusahan dalam mengerjakan tugas sekolah berada pada skor 23 dengan persentase 37\%, pada indikator 7 yaitu membuang sa,pah pada tempatnya berada pada skor 23 dengan persentase 37, serta pada indikator 8 yaitu tidak marah saat tidak mendapat mainan kesukaan berada pada skor 17 dengan persentase 27\%. Maka dapat disimpulka bahwa anak masih belum mampu taat peraturan, membantu temannya yang kesusahan dan juga bersabar ketika tidak mendapat yang dinginkan.

Tabel 4. Tabel Observasi Karakter Anak Pada Kondisi Pertemuan Ketiga

\begin{tabular}{clcccc}
\hline No & \multicolumn{1}{c}{ Komponen Indikator } & $\begin{array}{c}\text { Skor } \\
\text { Faktual }\end{array}$ & $\begin{array}{c}\text { Skor } \\
\text { Ideal }\end{array}$ & Kriteria \\
\hline 1. $\begin{array}{l}\text { Mengucapkan do'a-do'a pendek yaitu: } \\
\text { do'a sebelum belajar, do'a kedua orang } \\
\text { tua, do'a naik kendaraan }\end{array}$ & 40 & 63 & 63 & BSH \\
2. Mengucapkan Alhamdulillah & 50 & 63 & 79 & BSB \\
3. Menyelesaikan tugas dari sekolah secara & 35 & 63 & 56 & BSH
\end{tabular}




\begin{tabular}{|c|c|c|c|c|c|}
\hline 4. & Mentaati peraturan di sekolah & 30 & 63 & 48 & $\mathrm{MB}$ \\
\hline 5. & $\begin{array}{l}\text { Membantu teman yang kesusahan dalam } \\
\text { mengerjakan tugas sekolah }\end{array}$ & 37 & 63 & 59 & $\mathrm{BSH}$ \\
\hline 6. & $\begin{array}{l}\text { Bersalaman dengan orang tua ketika akan } \\
\text { masuk ke sekolah }\end{array}$ & 45 & 63 & 72 & $\mathrm{BSH}$ \\
\hline 7. & Membuang sampah pada tempatnya & 30 & 63 & 48 & $\mathrm{MB}$ \\
\hline \multirow[t]{2}{*}{8.} & $\begin{array}{l}\text { Tidak marah saat tidak mendapat mainan } \\
\text { kesukaan }\end{array}$ & 20 & 63 & 32 & $\mathrm{BB}$ \\
\hline & Jumlah & 287 & 63 & 457 & $\mathrm{BSH}$ \\
\hline
\end{tabular}

Berdasarkan hasil obsevasi di atas, dapat disimpulkan bahwa terdapat skor tertinggi pada indikator 2 yaitu mengucapkan Alhamdulillah dengan skor 50 dan persentase $79 \%$, sedangkan yang berada pada kategori BSH terdapat pada indikator no 1,3,5 dan 6, yaitu dengan indikator 1 mengucapkan do'a-do'a pendek yaitu: do'a sebelum belajar, do'a kedua orang tua, do'a naik kendaraan dengan skor 40 dan persentase $63 \%$, indikator 3 Menyelesaikan tugas dari sekolah secara mandiri dengan skor 35 dan persentase $56 \%$, indikator 5 Membantu teman yang kesusahan dalam mengerjakan tugas sekolah dengan skor 37 dan persentase $59 \%$, dan indikator 6 Bersalaman dengan orang tua ketika akan masuk ke sekolah berada pada skor 45 dan persentase $72 \%$. Sedangkan yang berada pada kategori MB terdapat pada indikator 7 yaitu membuang sampah pada tempatnya dengan sor 30 dan persentase $48 \%$, sedangkan yang berada pada kategori BB terdapat pada indikator 8 yaitu tidak marah saat tidak mendapat mainan kesukaan dengan skor 20 dan persentase $32 \%$.

Dalam penelitian ini, peneliti menemukan beragam karakter anak, bahwa yang yang dididik dengan pola asuh yang tepat, anak menjadi lebih disiplin, berani mengambil keputusan dan mampu bersikap baik kepada temannya maupun orang yang lebih tua darinya. Anak yang dididik dengan pola asuh selalu otoriter, anak menjadi pemalu, akan marah jika mainanannya diambil dan penakut. Sedangkan anak yang dididik dengan pola asuh cenderung permissive, maka anak selalu ingin mendapat apa yang ia inginkan, bersikap semaunya dan kurang taat peraturan, dan bersikap manja. Sehingga dalam pola asuh yang baik, orang tua harus mengkombinasikan serta menempatkan pola asuh yang tepat sesuai dengan situasinya.

\section{KESIMPULAN}

Berdasarkan hasil penelitian dapat disimpukan bahwa pola asuh orang tua di rumah berpengaruh terhadap karakter anak di Raudhatul Athfal Al-Fityah Pekanbaru dengan kategori tinggi dengan indeks 0,942 yang lebih besar dari " $\mathrm{r}$ " tabel pada taraf signifikan $1 \%=0,345$ maupun pada taraf signifikan 5\%=0,266. Sehingga koefisien determinasinya $\mathrm{r}^{2}=0,942^{2}=0,8873$. Berdasarkan hasil tabel tersebut maka jumlah distribusi variabel $\mathrm{X}$ terhadap variabel $\mathrm{Y}$ adalah sebesar $88,73 \%$ sedangkan $11,27 \%$ dipengaruhi oleh variabel lain yang tidak diteliti oleh 
peneliti sehingga $\mathrm{Ha}$ diterima dan $\mathrm{H}_{0}$ ditolak. Berarti ada pengaruh yang signifikan pola asuh orang tua di rumah terhadap karakter anak di Raudhatul Athfal Al-Fityah Pekanbaru. Dengan demikian dapat dikatakan bahwa semakin baik pola asuh orang tua maka semakin baik pula karakter anak di Raudhatul Athfal Al-Fityah Pekanbaru. Perlu perhatian dari segenap orang tua di rumah bahwa setiap perilaku, perkataan, dan cara orang tua mendidik anak secara tidak langsung akan mempengaruhi anak dalam bersikap dan bertutur kata. Maka hendaklah orang tua menjadi teladan yang baik bagi anak.

\section{DAFTAR PUSTAKA}

Hidayah, Rifa. (2009). Psikologi Pengasuban Anak. Malang: UIN Malang Press

Latif, Mukhtar. (2014). Orientasi Baru Pendidikan Anak Usia Dini. Jakarta: Kencana.

Mahmud, dkk. (2013). Pendidikan Agama Islam dalam Keluarga. Bandung: Akademia

Majid, Abdul Khon. (2012). Hadis Tarbawi: Hadis-hadis Pendidikan. Jakarta: Prenadamedia Group.

Marzuki. (2015). Pendidikan Karakter Islam. Jakarta: Amzah

Mulyasa, E. (2014). Manajemen PAUD. Bandung: Rosdakarya.

Najib, Muh. (2016). Manajemen Strategik Pendidikan Karakter Bagi Anak Usia

Noviyanti, Dian. (2013). Anak-Anak Kita Pengukir Peradaban. Bandung: PT.Elex Media Komputindo.

Rahmat, A, Rosyadi. (2013). Pendidikan Islam dalam Pembentukan Karakter Anak Usia Dini (Konsep dan Praktik PAUD Islami). Jakarta: PT Raja Grafindo Persada

Satriah, Lilis. (2011). Pendidikan Karakter dalam Keluarga. Cendekia Vol. 9 No 1

Anisah. 2015. Pola Asuh Orang Tua dan Implikasinya Terhadap Pembentukan Karakter Anak. Jurnal Pendidikan Universitas Garut Vol. 05. www.journal.uniga.ac.id 